\title{
Problems affecting the operational procurement process: A study of the Zimbabwean public sector
}

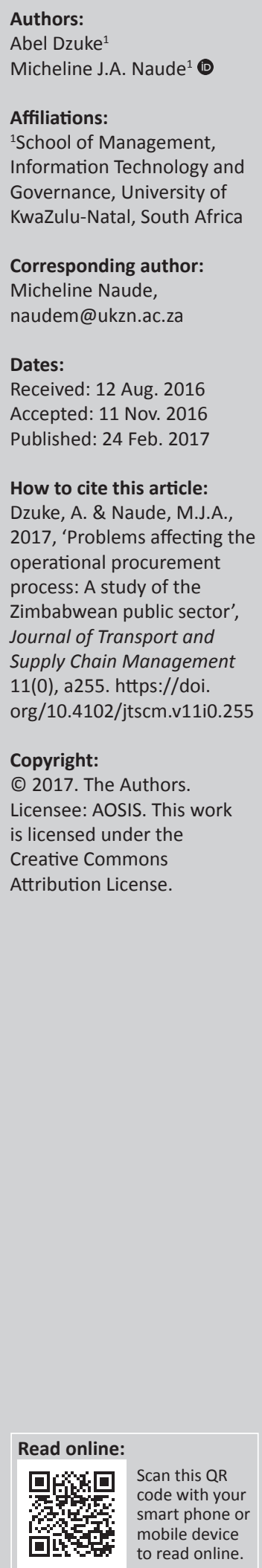

Background: The public sector occupies a key role in the economy comprising the appropriation of state revenue to purchase goods and to render services productively, while ensuring the optimum utilisation of available funds and resources to benefit the inhabitants of the country. Problems in the Zimbabwean public procurement sector that detract from service delivery are key contemporary issues. This is evident from the numerous complaints of poor service delivery received by the public that can be attributed to public procurement.

Objective: The purpose of this article was to report on a study that investigated problems in the different stages of the operational procurement process in the Zimbabwean public sector that detract from service delivery, the extent of these problems and how the public procurement process can be improved to enhance service delivery.

Method: This descriptive and exploratory study followed a quantitative approach. Data were collected by means of a questionnaire administered to all public entities in Zimbabwe. Data were analysed using SPSS.

Results: The majority of the identified problems in the public procurement sector that detract from service delivery are found in the advertising, bid evaluation and contract stages.

Conclusion: As only a few studies on this topic have been conducted in Zimbabwe, the findings of this research add a significant perspective to the existing body of knowledge and can assist stakeholders with regard to how the public procurement process can be improved in order to enhance service delivery through public procurement process reform and restructuring.

\section{Introduction and problem statement}

Globally, public procurement performs a key function in service delivery and the performance of government departments. It performs the fiduciary duty of ensuring efficient delivery of goods and services to the public (Uyarra \& Flanagan 2010:2) and involves all the processes related to the procurement of goods and services by government departments, parastatals and local authorities (Roodhooft \& Abbeele 2006:490). The public procurement process is governed by procurement laws and regulations, and differs from one country to another. Since public procurement accounts for a significant proportion of overall demand for goods and services (Uyarra \& Flannagan 2010:3), monetary values involved are significant, and it is the government's responsibility to ensure that resources are utilised in the most efficient, transparent and ethical manner to promote sustainable development of both the economy and standards of living (Seidu, Fatawu \& Ahmed 2014:4).

One of the main objectives of public procurement is to reduce cost through competition, promoting transparency, safeguarding public funds, as well as reducing and eliminating corruption (ADB/OECD 2008:11) in order to boost public service delivery (Vellapi 2010:4). According to UNDP/IAPSO (2006:1), public procurement has a direct effect on government performance, which is measured as service delivery. However, the implementation and results achieved are considerably affected by the differences in the socio-political environment, fundamental economic conditions and the technological environment of respective countries, as well as the laws governing procurement (Gayed 2013:2).

In Zimbabwe, it is estimated that $60 \%$ of government expenditure is allocated to public procurement, which is significant for a country that is facing liquidity challenges coupled with a lack of balance of payments support (Mushanyuri 2014:4). Subsequently, the public procurement system in Zimbabwe has been under scrutiny, with many blaming failures to implement government projects and initiatives on the public procurement process (Gayed 2013:9; Mushanyuri 2014:4). Earlier studies in public procurement and supply chain management have established 
that public procurement efficiency impacts on service delivery and public sector performance (Mutava 2012; Owuoth \& Mwangangi 2015; Sarfo \& Baah-Mintah 2013; Thuo \& Njeru 2014). A number of studies on public procurement have been published explaining the poor implementation of government projects and service delivery (Musanzikwa 2013; Tsabora 2014), and a preliminary study (Dzuke \& Naude 2015) has been published which focuses on the procurement challenges in the Zimbabwean public sector. This article focuses on problems affecting the operational procurement process that detract from service delivery in Zimbabwe.

In light of the poor service delivery in Zimbabwe (Chigudu 2014; Karombo 2014 \& Uromi 2014; Musanzikwa 2013), the objectives of this study are (1) to determine whether or not respondents agreed that problems identified in the first phase of the study are problematic in the procurement process, (2) to measure the extent to which the entities are experiencing these problems and (3) to identify whether the problems detract from service delivery in the various stages of the public procurement process.

The article commences with an introduction to the study containing the background, an overview of previous studies and the purpose of the study. This is followed by a literature review that includes an overview of public service delivery and public procurement and provides insight into problems that detract from service delivery in Zimbabwe. Thereafter, the method of research is presented, followed by the findings and discussion thereof. The article will wrap up with the limitations and conclusion.

\section{Literature review \\ Public service delivery}

Public services are services that are provided by public entities to its citizens. Effective and efficient public service should be available to all, regardless of social or economic position (Wanna, Butcher \& Freyens 2010:1). Le Grand (2009:7) lists the following five attributes of a good public service: it (1) should be of high quality (e.g. clean and safe drinking water and efficient public transport systems), (2) should be managed and operated efficiently, (3) should be responsive to the needs and wants of users, (4) should be accountable to taxpayers and (5) should be delivered equitably.

Public service delivery is funded by tax collected from taxpayers, is not subjected to the rules of the free market and there is no incentive to create value for tax payers' money (Johnson \& Flynn 2015:525; Van Weele 2014:375). However, Vellapi (2010:4) comments that the main aim of public procurement is to create value and improve service delivery. Weishaar (2013:243) is of the opinion that the concept of creating value in public procurement relates to the contribution made in achieving government policy and objectives, while achieving the best returns against the tax paid by the taxpayer.
Public service is a fundamental precursor of quality of life and a basis to minimise poverty (Besley \& Ghatak 2007:147). Service delivery consists of distributing basic resources citizens depend on, such as water, electricity, sanitation infrastructure, land and housing (Murimoga \& Musingafi 2014:99). Unfortunately, Zimbabwe has a deteriorating infrastructure, lack of clean water, as well as erratic service delivery (International Republican Institute 2015:27).

In 2015, a study by the International Republican Institute was conducted in Zimbabwe, to identify citizens' perceptions of the roles and responsibilities of locally elected councillors and traditional leaders with regard to local governance and service delivery. The findings revealed that the main service delivery problem was poor infrastructure followed by lack of clean water, poor refuse collection and limited access to health care. The main reasons given by respondents as to why infrastructure was poor included poor maintenance, lack of funding and inefficiency, and incompetence on the part of government (Chirisa 2010:3; International Republican Institute 2015:27).

\section{Public procurement}

Public procurement can be described as the procurement of goods and services on behalf of a public authority. It is funded by the taxpayers' money and as a result there is a need to create the best value for the taxpayers' money (Van Weele 2014:375). It is the process whereby public sector entities acquire goods, services and works from third parties of routine items (e.g. stationery) to complex expenditures (e.g. construction of roads) (Monczka et al. 2008:2; Van Weele 2014:376).

Globally, public procurement plays a key role in service delivery and the performance of public entities (Dzuke \& Naude 2015:1). Public procurement constitutes $18.42 \%$ of the world's gross domestic product (Mahmood 2010:12). This is supported by Hetland (2012) who remarks that public procurement accounts for a significant share of governments' annual expenditures globally, with governments spending approximately \$11 trillion per annum on public procurement. In developing countries, it is estimated that procurement amounts to approximately $25 \%$ of the gross domestic product (La Harpe \& Le Roux 2009:18). Consequently, public procurement is of great importance to the economy of a country.

Public procurement is a regulated, open process defined and controlled by numerous laws, rules and regulations (Naude, Ambe \& Kling 2013:3). It has its origins in the fiduciary obligation to deliver goods and services to the residents of a particular country and addresses a wide range of objectives. For one, it has been used by governments to achieve socioeconomic objectives such as stimulating economic activity, protecting industries from foreign competition and improving the competitiveness of certain industrial sectors (Ambe \& Badenhorst-Weiss 2012:244). 
In Zimbabwe, the public procurement process is governed by the Procurement Act (22:14) as read with the Procurement Regulations Statutory Instrument 170 of 2002 regulations and rules, covering the making of procurement decisions. The laws and regulations stipulate how government officials must follow a set system for procurement. For example, how they advertise for suppliers, how to deal with suppliers and how to award contracts. The aim of such a system is to take advantage of competition between suppliers and to reduce the risk of corruption (Van Weele 2014:377).

The principal law in public procurement in Zimbabwe is the Procurement Act (22:14) of 2002 as read with the Procurement Regulations (Statutory Instrument 171 of 2002). The Procurement Regulations (Statutory Instrument 171 of 2002) is a key piece of legislation, which draws attention to the procurement cycle, the procurement methods and contract management. Equally significant are the Statutory Instrument 159 of October 2012, which stipulates the administration fees, and the Statutory Instrument 19 of February 2015, which specifies the procurement thresholds applicable to public procurement (Statutory Instrument 19 of February 2015 amended Statutory Instrument 160 of October 2012).

The forerunner of the State Procurement Board (SPB), known as the Government Tender Board, was abolished in 2002. The SPB, the regulatory body for public procurement in Zimbabwe, was established in terms of Section 4 of the Procurement Act (22:14) of 1999 and was gazetted in 2002. In the Procurement Act and Regulations, the SPB is referred to as the 'Authority'.

The public procurement process adopted in Zimbabwe consists of five stages. Figure 1 presents the stages in the public procurement process with a summary of what is involved in each step.

\section{Problems in Public Procurement that detract from service delivery}

Globally, public procurement is central to the delivery of public services and performance of public entities (Dzuke \& Naude 2015:1). Various scholars identified the following key problems in the public procurement system: (1) weak and outdated procurement policies and processes, (2) public sector procurement remaining an operational activity and not a strategic activity, (3) a lack of accountability and transparency; a lack of procurement knowledge and skill, (4) embedded fraud and corruption and (5) the inability to implement appropriate reforms (Ameyaw, Mensah \& OseiTutu 2012; Hunja 2003; Mamiro 2010; Nkinga 2003). Licenji (2015:239) observed that the lack of appropriate skills and specialised knowledge are significant problems in public procurement, as procurement officers are required to provide value for money and take into account strategic considerations.

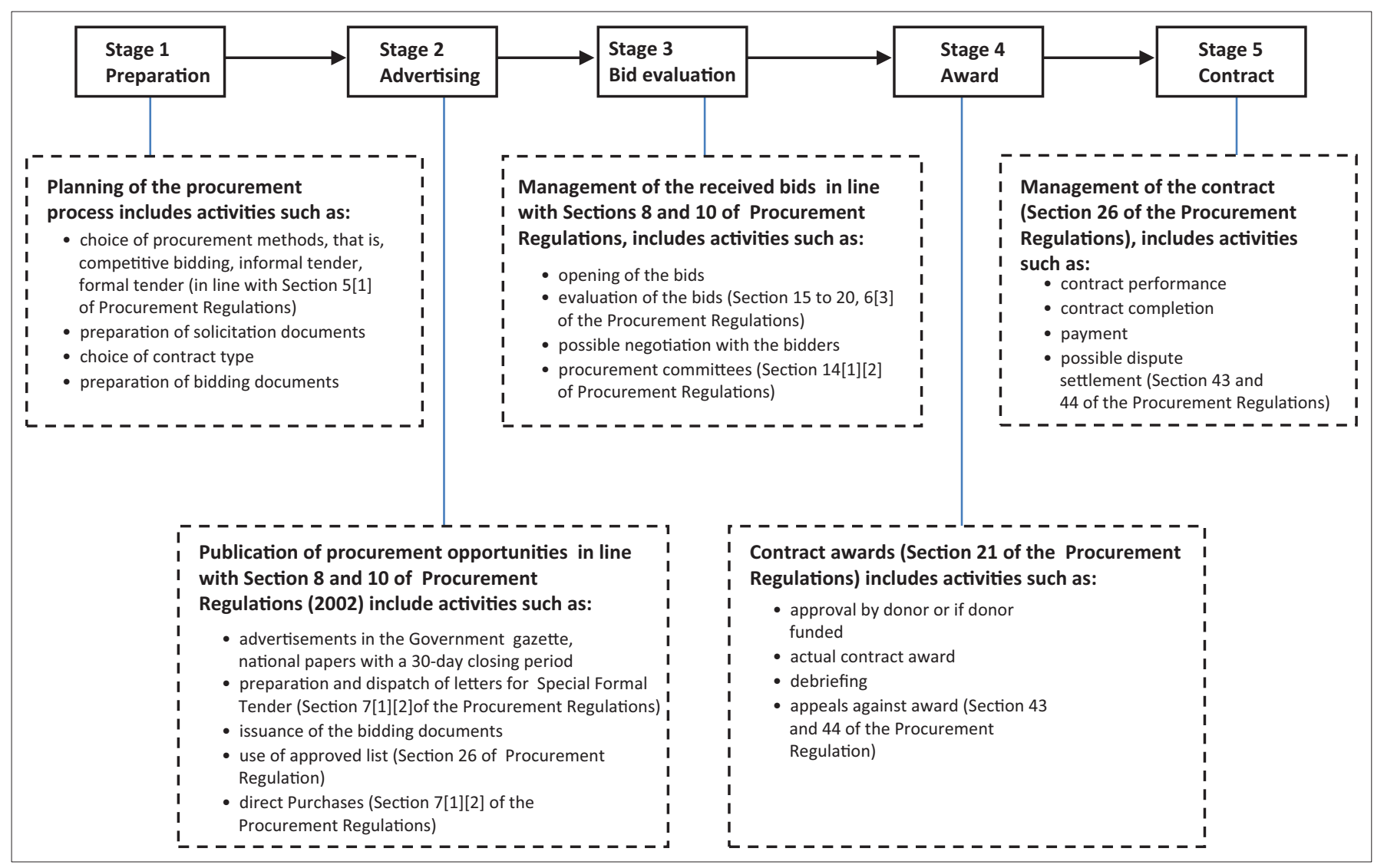

Source: Adapted from the Procurement Act (Chapter 22:14; Act No. 2 of 1999) (Zimbabwe Government 1999) and the Procurement Regulations, Statutory Instrument (171 of 2002) (Zimbabwe Government 2002)

FIGURE 1: Stages in the public procurement process in Zimbabwe. 
Dza, Fischer and Gapp (2013:53) observed that political interference in the procurement process is a problem to the successful implementation of public procurement in Africa. In most African countries, politicians influence the tender process, insisting that particular contracts are awarded to individuals or companies of their choosing. In sub-Saharan Africa, Ringwald and Ndercaj (2014:6) identified the following common problems affecting public sector procurement: (1) the lack of transparency, accountability and integrity in policy and process, (2) the lack of professional, managerial and leadership skills, (3) the lack of strategic recognition for the procurement function, (4) the continued failure to implement appropriate change and (5) weak and outdated procurement policies and processes.

In South Africa, despite the reform processes in public procurement and the employment of supply chain management as a strategic tool, problems identified in the public procurement practices included non-compliance with legislation and policies related to procurement and supply chain management, as well as tender irregularities (Ambe \& Badenhorst-Weiss 2012:242). Livhuwani (2012:44) found that the supply chain management section in Limpopo was experiencing problems of poor service delivery as a result of insufficient training, lack of experience and inadequate qualifications. This resulted in the failure of the procurement personnel to interpret policies, acts, rules and regulations that govern supply chain management, and they tended to award contracts to unqualified service providers who bribed public officials via monetary reward.

Since the aim of this article was to identify problems in the procurement process that detract from achieving service delivery in Zimbabwe, it is appropriate that a section, which provides insight into some of the problems identified by other researchers, in the Zimbabwean public sector, be included.

A study conducted by Musanzikwa (2013:125) reveals the following challenges in public procurement: (1) delays in making decisions, (2) corruption and (3) the need to comply with SPB procedures. The latter resulted in major delays in government projects, for example, the construction of a \$600 000 district hospital in Gokwe North, lagging behind schedule and taking years to complete. Other studies reveal problems such as lack of procurement ethics (Shaw 2010), incompetence - attributed to lack of qualifications and/or training (Ameyaw et al. 2012:61).

Chimberengwa et al. (2015:1) attribute poor service delivery in Zimbabwe to problems in the procurement process. These problems include stock shortages of essential goods such as medicines, and also the poor quality of procured goods, and are attributed to a lack of proper procurement planning, cumbersome procurement processes, as well as ignorance of procurement processes, procurement policies and legislation.

Dzuke and Naude (2015:6) remark that the requirements of the legal framework is a major challenge which is mainly caused by the fact that every stage and activity of the process is regulated and is exacerbated by the requirement that all activities, such as approval of tender documents and adverts, tender closing as well as evaluation, must involve the SPB.

\section{Method of research}

The study is exploratory and descriptive - it consists of a quantitative approach with some qualitative aspects. Qualitative and quantitative research was used since both approaches provide different perspectives and they usually complement each other to achieve the best insights (Creswell 2013:215).

This article reports on a study that was conducted to investigate procurement problems that detract from service delivery in the Zimbabwean public sector. To achieve the objectives of the study, secondary and primary research were carried out. The primary research comprised two phases explained in the following two sections.

\section{Phase I}

The purpose of the first phase of the empirical study was to identify problems in the public procurement process that detract from public service delivery.

This phase consisted of semi-structured in-depth interviews with five participants at two ministries and three public entities (Table 1). The population of this study is made up of 25 ministries and 52 public entities in Zimbabwe. A nonprobability convenience sample technique was used to select the public entities. Two ministries were selected because they provide critical services - being the ministries of health and transport, and the three public entities were selected on the basis of the services they provide - energy, the distribution of antiretroviral drugs and fuel.

In order to ensure reliability of the data, interviews were recorded using a digital voice recorder to ensure that the data collected were accurate. Once potential problems in the public procurement process were identified, a questionnaire (Phase II) was designed that included the problems identified from literature and the semi-structured interviews.

\section{Phase II}

The aim of the second phase of the empirical research was to address the objectives of this study - (1) to determine whether

TABLE 1: List of participants.

\begin{tabular}{|c|c|c|}
\hline Participant & Participating entity & Position \\
\hline Participant 1 & $\begin{array}{l}\text { Ministry of Health and } \\
\text { Child Welfare }\end{array}$ & Procurement Officer \\
\hline Participant 2 & $\begin{array}{l}\text { Ministry of Transport and } \\
\text { Infrastructural Development }\end{array}$ & $\begin{array}{l}\text { Administrator - Procurement } \\
\text { and Contracts }\end{array}$ \\
\hline Participant 3 & Zimbabwe Power Company & Procurement Officer \\
\hline Participant 4 & PetroTrade Zimbabwe & Procurement Manager \\
\hline Participant 5 & National Aids Council & Procurement Officer \\
\hline
\end{tabular}


respondents agreed or not that problems identified in the first phase of the study are problematic in the procurement process, (2) to measure the extent to which the entities are experiencing these problems and (3) to assess whether the problems detract from service delivery in the various stages of the public procurement process.

The questionnaire consisted of two parts. The first part provided general information about the study. The second part comprised the profile of the respondents and the problems relating to each stage in the procurement process. The questionnaire consisted of closed and open-ended questions. The closed questions were arranged in sections and a comments section was given at the end of each section so that respondents would be able to elaborate or comment on the sections. Items were measured on a seven-point Likert scale, varying from 1 (to a lesser extent) to 7 (to a greater extent). A seven-point Likert scale was deemed appropriate, as it reflects an inclusive, exhaustive and mutually exclusive category and results in more precise data with a high level of reliability and validity and more meaningful statistical results as well as fewer neutral and uncertain responses (Finstad 2010:108; Pearse 2011:163).

Since there are 77 parastatals in Zimbabwe, all units were included in the study. As the ministries and public entities have head offices in Harare, except one in Bulawayo (which has a regional office in Harare), a hard copy was handed out by one of the authors at each parastatal to the most senior respondent heading the procurement department (i.e. directors, procurement managers and administration managers). There is no standard procurement structure applying across the public sector, with the procurement section of the larger entities being headed by a procurement director/manager, and with the smaller entities and ministries led by administration managers or officers. Respondents were given 30 days to complete the questionnaire. To ensure a high response rate, after 2 weeks, the researcher followed up with the respondents to remind them to complete the questionnaire. This was done telephonically or through email. The researcher then collected the completed questionnaires from the individuals concerned. The data were collected between 05 January and 27 March 2015.

Of the 77 questionnaires that were handed out, 64 questionnaires were completed. Therefore, a response rate of $83.1 \%$ was achieved. All questionnaires were used in the data analysis with none excluded, as they were all fully completed. The completed questionnaires were coded and the responses captured in Excel and analysed by means of SPSS21 by a statistician. The study used descriptive statistics. The qualitative comments were transcribed in a report format, after which it became possible to review, compare and combine the findings of each respondent. The transcripts were checked for accuracy and correctness by one of the authors.

\section{Reliability and validity}

Reliability is explained as a random error in measurement and it indicates the accuracy of the measuring instrument, that is, whether the instrument consistently measures what it is supposed to measure (McDaniel \& Gates 2013:215). Pilot testing of the questionnaire can be done to test the reliability of an instrument (McDaniel \& Gates 2013:263; Radhakrishna 2007:3). Validity is the extent to which the data collection method measures what it is designed to measure (Creswell 2013:143). Validity of the data collected was measured by pre-testing the questionnaire with respondents at three public entities. The rationale behind the pilot study was to fine-tune the questions so that respondents would be clear on what exactly was being asked, and would have no challenges responding to the questions. Once the questionnaire had been returned and tested, it was refined before being sent out to all the ministries and parastatals. Consequently, the questionnaire was tested for (1) face validity, which indicates that the items included in the questionnaire are clear and understandable to the respondents and (2) content validity to ensure that the measures include a sufficient and representative set of items that draw on the concept (Sekaran \& Bougie 2009:159).

The results of the study are dealt with in the Results section. Firstly, the distribution of the responses of those who indicated that the problems outlined in this questionnaire are problematic in the procurement process is provided in the next section on findings. Secondly, in order to determine the extent of problems, data for mean, median, quartiles and number of valid cases are given. The median shows the middle of the data and on a scale of 1-7 in the questionnaire, the median is 3.5. Thirdly, binomial tests were conducted to determine whether a significant proportion of respondents agreed that the identified items present problems that detract from service delivery. The binomial test is an exact test of the statistical significance of deviations from a theoretically expected distribution of observations into two categories. The test is done at $5 \%$ level of significance.

\section{Results \\ Profile of respondents}

Table 2 presents the details of the gender, age and employment position of the respondents that participated in this study $(N=64)$.

\section{Stage 1: Preparation stage}

This section presents the problems in the preparation stage that detract from service delivery. These include nine problems whose means range from 3.38 to 4.75 (see Table 3). The number of valid cases in the table represents the respondents who identified problems in the procurement process. The respondents were then asked to rank the extent of these problems and whether or not they detract from service delivery. 
Table 3 indicates that a significant percentage of respondents agreed that the listed items present problems during the preparation stage. However, the binomial test in Table 3 reveals that not all these problems detract from service delivery. The ones that do are the following: (1) poor selection of appropriate procurement method $(p=0.010)$, (2) length of time taken to prepare a draft request for proposal (RFP) and advertisement and submit to the SPB $(p=0.040)$ and (3) length of time taken to approve RFP at the SPB $(p<0.05)$. Lack of standard bidding documents $(p=0.017)$ is a problem that does not detract from service delivery.

\section{Stage 2: Advertising stage}

This section presents the problems identified in the advertising stage that detract from service delivery. A total of six problems were identified where the means range from 3.59 to 4.90 .

Table 4 shows that a substantial proportion of respondents agreed that the listed items present problems during the advertising stage. However, the binomial test in Table 4 reveals that a significant proportion of respondents agreed that the following problems during the preparation stage detract from service delivery: (1) amount of time taken to approve the RFP and advertisement $(p=0.014),(2)$ the length of time taken in the use of the special formal tenders process $(p<0.05)$, (3) the time taken in the process of using direct purchase $(p<0.05)$ and $(4)$ the length of the process followed in the use of approved lists $(p=0.022)$.

\begin{tabular}{lcc} 
TABLE 2: Profile of respondents. & & \\
\hline Profile & $N=64$ & $\%$ \\
\hline Gender & 46 & 71.9 \\
$\quad$ Male & 18 & 23.1 \\
$\quad$ Female & & \\
Age & 49 & 76.6 \\
$\quad$ 20-30 years & 15 & 23.4 \\
31-40 years & & \\
Position & 35 & 54.7 \\
Procurement manager & 23 & 35.9 \\
Administration & 6 & 9.4 \\
$\quad$ Managing Directors & & \\
\hline
\end{tabular}

\section{Stage 3: Bid Evaluation Stage}

This section deals with the problems that detract from service delivery during the evaluation stage. A total of 13 problems were identified where the means range from 5.80 to 6.91 .

Table 5 shows that a significant proportion of respondents agreed that the listed items present significant problems in the evaluation stage. However, the binomial tests in Table 5 reveal that a significant proportion agreed that the following problems in the evaluation stage detract from service delivery: (1) poor selection criteria for procurement committee members ( $p=0.002)$, (2) evaluation team members' lack of training in procurement $(p<0.05)$, (3) evaluation team members lack of knowledge of procurement ethics $(p<0.05)$, (4) evaluation team members' lack of expertise in tender evaluation $(p<0.05)$, (5) poor interpretation of evaluation criteria $(p<0.05)$, (6) the use of $100 \%$ compliance award criteria $(p<0.05)$, (7) supplier approved list registration criteria at the SPB $(p<0.05)$, (8) absence of supplier appraisals and rating $(p<0.05),(9)$ amount of time taken for evaluation at SPB $(p<0.05)$ and $(10)$ non-concurrence of entity and SPB evaluation $(p=0.001)$.

\section{Stage 4: Award stage}

This section deals with the problems that detract from service delivery during the award stage. As can be seen from Table 6, a total of six problems were identified where the means range from 3.80 to 6.26 , of which only three detract from service delivery.

Table 6 shows that a significant proportion of respondents agreed that the listed items present significant problems during the award stage. However, the binomial test in Table 6 reveals that a significant proportion agreed that only three of the six problems in the award stage detract from service delivery: (1) the 20-day period given to losing bidders to lodge appeals at court $(p=0.010)$, (2) the suspension of contract signing owing to appeals by losing bidders $(p<0.05)$ and (3) the amount of time required for the finalisation of the court process $(p<0.05)$.

TABLE 3: Problems in the preparation stage.

\begin{tabular}{|c|c|c|c|c|c|c|c|c|c|}
\hline \multirow[t]{2}{*}{ Number } & \multirow[t]{2}{*}{ Problems } & \multirow[t]{2}{*}{ Mean } & \multirow[t]{2}{*}{ Median } & \multicolumn{2}{|c|}{ Quartiles } & \multirow{2}{*}{$\begin{array}{c}\text { Respondents } \\
(N=64): \text { Number of } \\
\text { valid cases } \dagger\end{array}$} & \multicolumn{2}{|c|}{ Detracts from service delivery } & \multirow{2}{*}{$\begin{array}{l}\text { Asymp. Sig. } \\
\text { (2-tailed): }\end{array}$} \\
\hline & & & & 25 & 75 & & Yes & No & \\
\hline 1 & Lack of procurement plans & 3.70 & 4.00 & 2.00 & 5.00 & 53 & 33 & 20 & 0.098 \\
\hline 2 & $\begin{array}{l}\text { Poor selection of appropriate } \\
\text { procurement method }\end{array}$ & 4.44 & 5.00 & 3.00 & 6.00 & 43 & 31 & 13 & 0.010 \\
\hline 3 & $\begin{array}{l}\text { Inadequate procurement thresholds for } \\
\text { your operations }\end{array}$ & 4.48 & 5.00 & 3.00 & 6.00 & 48 & 25 & 23 & 0.885 \\
\hline 4 & Lack of standard bidding documents & 3.38 & 3.00 & 2.00 & 5.00 & 64 & 22 & 42 & 0.017 \\
\hline 5 & $\begin{array}{l}\text { Lack of expertise in the preparation of } \\
\text { the RFP }\end{array}$ & 4.07 & 4.00 & 2.00 & 6.00 & 55 & 26 & 27 & 1.000 \\
\hline 6 & $\begin{array}{l}\text { Length of time taken to prepare a draft RFP } \\
\text { and advert and submit to SPB }\end{array}$ & 4.48 & 5.00 & 3.00 & 6.00 & 54 & 35 & 19 & 0.040 \\
\hline 7 & Length of time taken to approve RFP at SPB & 4.60 & 5.00 & 4.00 & 6.00 & 57 & 45 & 12 & 0.000 \\
\hline 8 & $\begin{array}{l}\text { Lack of technical expertise to approve } \\
\text { RFPs at SPB }\end{array}$ & 3.98 & 4.00 & 2.00 & 6.00 & 51 & 27 & 23 & 0.672 \\
\hline 9 & $\begin{array}{l}\text { Lack of training on preparation of RFPs } \\
\text { by SPB }\end{array}$ & 4.75 & 6.00 & 3.00 & 6.00 & 56 & 31 & 23 & 0.341 \\
\hline
\end{tabular}

RFP, request for proposal; SPB, State Procurement Board.

$\dagger$, Number of respondents who indicated this to be a problem; $\$$, based on Z Approximation. 
TABLE 4: Problems in the advertising stage.

\begin{tabular}{|c|c|c|c|c|c|c|c|c|c|}
\hline \multirow[t]{2}{*}{ Number } & \multirow[t]{2}{*}{ Problems } & \multirow[t]{2}{*}{ Mean } & \multirow[t]{2}{*}{ Median } & \multicolumn{2}{|c|}{ Quartiles } & \multirow{2}{*}{$\begin{array}{l}\text { Respondents } \\
(N=64): \text { Number } \\
\text { of valid cases } \dagger\end{array}$} & \multicolumn{2}{|c|}{ Detracts from service delivery } & \multirow{2}{*}{$\begin{array}{l}\text { Asymp. Sig } \\
\text { (2-tailed) }\end{array}$} \\
\hline & & & & 25 & 75 & & Yes & No & \\
\hline 1 & $\begin{array}{l}\text { Delay in determining of publication and closing } \\
\text { dates at SPB }\end{array}$ & 3.59 & 3.00 & 2.00 & 5.00 & 56 & 26 & 30 & 0.689 \\
\hline 2 & Amount of time taken to approve the RFP and advert & 4.32 & 4.00 & 3.00 & 5.00 & 56 & 37 & 18 & 0.014 \\
\hline 3 & $\begin{array}{l}\text { The amount of time taken from RFP approval to } \\
\text { the actual publication }\end{array}$ & 4.36 & 5.00 & 3.00 & 6.00 & 59 & 38 & 21 & 0.036 \\
\hline 4 & $\begin{array}{l}\text { The length of time taken in the use of the special } \\
\text { formal tenders process }\end{array}$ & 4.82 & 5.00 & 4.00 & 6.00 & 61 & 47 & 12 & 0.000 \\
\hline 5 & The time taken in the process of using direct purchase & 4.90 & 5.00 & 3.75 & 6.00 & 58 & 44 & 14 & 0.000 \\
\hline 6 & $\begin{array}{l}\text { The length of process followed in the use of } \\
\text { approved lists }\end{array}$ & 4.51 & 5.00 & 3.00 & 6.00 & 55 & 37 & 19 & 0.022 \\
\hline
\end{tabular}

SPB, State Procurement Board; RFP, request for proposal.

$\dagger$, Number of respondents who indicated this to be a problem; $\downarrow$, based on Z Approximation.

TABLE 5: Problems in the bid evaluation stage.

\begin{tabular}{|c|c|c|c|c|c|c|c|c|c|}
\hline \multirow[t]{2}{*}{ Number } & \multirow[t]{2}{*}{ Problems } & \multirow[t]{2}{*}{ Mean } & \multirow[t]{2}{*}{ Median } & \multicolumn{2}{|c|}{ Quartiles } & \multirow{2}{*}{$\begin{array}{c}\text { Respondents } \\
(N=64): \text { Number } \\
\text { of valid cases } \dagger\end{array}$} & \multicolumn{2}{|c|}{ Detracts from service delivery } & \multirow{2}{*}{$\begin{array}{l}\text { Asymp. Sig } \\
\text { (2-tailed) } \$\end{array}$} \\
\hline & & & & 25 & 75 & & Yes & No & \\
\hline 1 & $\begin{array}{l}\text { Amount of time taken to be invited to collect } \\
\text { tender documents }\end{array}$ & 3.91 & 4.00 & 3.00 & 5.00 & 56 & 22 & 34 & 0.141 \\
\hline 2 & $\begin{array}{l}\text { Inadequate amount of time provided to evaluate } \\
\text { tenders at the entity level }\end{array}$ & 3.96 & 4.00 & 2.00 & 5.50 & 53 & 28 & 25 & 0.784 \\
\hline 3 & $\begin{array}{l}\text { The number of people involved in the evaluation } \\
\text { process at the entity level }\end{array}$ & 3.93 & 4.00 & 2.00 & 5.00 & 55 & 25 & 30 & 0.590 \\
\hline 4 & $\begin{array}{l}\text { Poor selection criteria for procurement committee } \\
\text { members }\end{array}$ & 4.86 & 4.00 & 2.00 & 5.00 & 55 & 42 & 17 & 0.002 \\
\hline 5 & $\begin{array}{l}\text { Evaluation team members' lack of training in } \\
\text { procurement }\end{array}$ & 5.64 & 5.00 & 5.00 & 7.00 & 61 & 57 & 4 & 0.000 \\
\hline 6 & $\begin{array}{l}\text { Evaluation team members' lack of knowledge of } \\
\text { procurement ethics }\end{array}$ & 5.60 & 6.00 & 5.00 & 7.00 & 60 & 50 & 10 & 0.000 \\
\hline 7 & $\begin{array}{l}\text { Evaluation team members' lack of expertise in } \\
\text { tender evaluation }\end{array}$ & 5.13 & 6.00 & 4.00 & 6.00 & 60 & 49 & 12 & 0.000 \\
\hline 8 & Poor interpretation of evaluation criteria & 4.83 & 5.00 & 4.00 & 6.00 & 59 & 48 & 11 & 0.000 \\
\hline 9 & The use of $100 \%$ compliance award criteria & 5.44 & 6.00 & 4.00 & 7.00 & 59 & 52 & 7 & 0.000 \\
\hline 11 & Absence of supplier appraisals and rating & 5.80 & 6.00 & 5.00 & 7.00 & 60 & 54 & 6 & 0.000 \\
\hline 12 & Amount of time taken for evaluation at SPB & 4.85 & 5.00 & 4.00 & 6.00 & 59 & 47 & 12 & 0.000 \\
\hline 13 & Non-concurrence of entity and SPB evaluation & 4.37 & 4.00 & 4.00 & 5.25 & 54 & 39 & 15 & 0.001 \\
\hline
\end{tabular}

SPB, State Procurement Board.

$\dagger$, Number of respondents who indicated this to be a problem; $\ddagger$, based on Z Approximation.

TABLE 6: Problems in the award stage.

\begin{tabular}{|c|c|c|c|c|c|c|c|c|c|}
\hline \multirow[t]{2}{*}{ Number } & \multirow[t]{2}{*}{ Problems } & \multirow[t]{2}{*}{ Mean } & \multirow[t]{2}{*}{ Median } & \multicolumn{2}{|c|}{ Quartiles } & \multirow{2}{*}{$\begin{array}{c}\text { Respondents } \\
(N=64): \text { Number of } \\
\text { valid cases } \dagger\end{array}$} & \multicolumn{2}{|c|}{ Detracts from service delivery } & \multirow{2}{*}{$\begin{array}{l}\text { Asymp. Sig. } \\
(2 \text {-tailed) }\end{array}$} \\
\hline & & & & 25 & 75 & & Yes & No & \\
\hline 1 & $\begin{array}{l}\text { Amount of time taken by SPB to notify bidders' } \\
\text { entities on tender results }\end{array}$ & 3.84 & 4.00 & 3.00 & 5.00 & 50 & 25 & 24 & 1.000 \\
\hline 2 & $\begin{array}{l}\text { Amount of time taken to enter into contract with } \\
\text { winning bidders }\end{array}$ & 3.85 & 3.00 & 2.00 & 6.00 & 52 & 22 & 30 & 0.332 \\
\hline 3 & The period given to losing bidders to seek debriefs & 3.80 & 3.00 & 2.75 & 5.25 & 50 & 19 & 33 & 0.070 \\
\hline 4 & $\begin{array}{l}\text { The 20-day period given to losing bidders to lodge } \\
\text { appeals at court }\end{array}$ & 4.86 & 5.00 & 3.25 & 6.00 & 56 & 38 & 18 & 0.010 \\
\hline 5 & $\begin{array}{l}\text { The suspension of contract signing owing to } \\
\text { appeals by losing bidders }\end{array}$ & 5.44 & 6.00 & 5.00 & 7.00 & 54 & 42 & 12 & 0.000 \\
\hline 6 & $\begin{array}{l}\text { The amount of time required for the finalisation of } \\
\text { the court process }\end{array}$ & 6.26 & 7.00 & 6.00 & 7.00 & 53 & 46 & 7 & 0.000 \\
\hline
\end{tabular}

SPB, State Procurement Board.

$\dagger$, Number of respondents who indicated this to be a problem; $\$$, based on Z Approximation.

\section{Stage 5: Contract stage}

This section deals with the problems that detract from service delivery during the award stage. As can be seen from Table 7, a total of seven problems were identified where the means range from 3.56 to 6.05 , five of which detract from service delivery.

Table 7 shows that a significant proportion of respondents agreed that the listed items present significant problems during the contract stage. However, the binomial tests reveal that a significant proportion of the respondents agreed that the following problems in the contract stage detract from service delivery: (1) duration of contract negotiations with winning bidders $(p=0.033)$, (2) lack of contract monitoring mechanisms and the suspension of contract signing owing to appeals by losing bidders $(p=0.012)$, (3) lack of SPB involvement in contract monitoring $(p<0.05)$, (4) lack of SPB action on poor 
TABLE 7: Problems in the contract stage.

\begin{tabular}{|c|c|c|c|c|c|c|c|c|c|}
\hline \multirow[t]{2}{*}{ Number } & \multirow[t]{2}{*}{ Problems } & \multirow[t]{2}{*}{ Mean } & \multirow[t]{2}{*}{ Median } & \multicolumn{2}{|c|}{ Quartiles } & \multirow{2}{*}{$\begin{array}{l}\text { Respondents } \\
(N=64): \text { Number } \\
\text { of valid cases } \dagger\end{array}$} & \multicolumn{2}{|c|}{ Detracts from service delivery } & \multirow{2}{*}{$\begin{array}{l}\text { Asymp. Sig } \\
\text { (2-tailed) } \$\end{array}$} \\
\hline & & & & 25 & 75 & & Yes & No & \\
\hline 1 & $\begin{array}{l}\text { Extended period taken to invite bidders to } \\
\text { sign contracts }\end{array}$ & 3.73 & 3.00 & 2.00 & 6.00 & 51 & 24 & 27 & 0.780 \\
\hline 2 & $\begin{array}{l}\text { Duration of contract negotiations with } \\
\text { winning bidders }\end{array}$ & 3.56 & 3.5 & 2.00 & 5.00 & 54 & 24 & 32 & 0.033 \\
\hline 3 & Lack of contract monitoring mechanisms & 4.96 & 5.00 & 4.00 & 6.50 & 57 & 37 & 20 & 0.012 \\
\hline 4 & $\begin{array}{l}\text { Lack of SPB involvement in contract } \\
\text { monitoring }\end{array}$ & 5.48 & 6.00 & 4.75 & 7.00 & 58 & 39 & 19 & 0.000 \\
\hline 5 & $\begin{array}{l}\text { Lack of SPB action on poor performing } \\
\text { suppliers }\end{array}$ & 6.05 & 7.00 & 5.00 & 7.00 & 62 & 49 & 13 & 0.000 \\
\hline 6 & $\begin{array}{l}\text { Failure by entities to take action when } \\
\text { suppliers do not meet performance } \\
\text { standards }\end{array}$ & 5.42 & 6.00 & 4.25 & 7.00 & 60 & 47 & 13 & 0.000 \\
\hline 7 & $\begin{array}{l}\text { Failure to conduct procurement audits by } \\
\text { the SPB }\end{array}$ & 5.79 & 7.00 & 5.00 & 7.00 & 61 & 47 & 14 & 0.000 \\
\hline
\end{tabular}

SPB, State Procurement Board.

$\dagger$, Number of respondents who indicated this to be a problem; $\downarrow$, based on Z Approximation.

performing suppliers, (5) failure by entities to take action when suppliers do not meet performance standards $(p<0.05)$ and $(6)$ failure to conduct procurement audits by the SPB $(p<0.05)$.

\section{Discussion}

In this section, the outline of the significant procurement problems that detract from service delivery is provided together with practical implications.

\section{Significant procurement problems}

Figure 2 presents a summary of the significant procurement problems that detract from service delivery during each stage of the public procurement process in Zimbabwe.

\section{Stage 1: Preparation stage}

Poor selection of appropriate procurement methods is when the procuring entities end up selecting a wrong procurement method against Statutory Instrument 160 of October 2012 of the procurement regulations for thresholds (mean of 4.44) and is a problem that detracts from service delivery. This has been attributed to lack of training in public procurement by the SPB. The problem of incompetence owing to lack of training was also recognised in the literature (Ameyaw et al. 2012:61; Shaw 2010).

The lack of training in the preparation of RFPs by the SPB (mean of 4.75), coupled with the lack of standard bidding documents (3.38), is a problem, the former detracting from service delivery. This can be attributed to inconsistencies in tender documents and procurement processes for similar procurement situations. The amount of time taken to prepare a draft RFP and advertisement and submit these to the SPB (mean of 4.48) are the result of a lack of proper training and education with regard to how the documents should be prepared. Chimberengwa et al. (2015:1) concur with these findings, and they attribute poor service delivery in Zimbabwe to problems attributed to a lack of proper procurement planning, cumbersome procurement processes, as well as ignorance of procurement processes, procurement policies and legislation. As indicated by respondents in the qualitative comments of the questionnaire, the SPB needs to provide such training. Therefore, in order to overcome this problem, it is recommended that the SPB take the initiative and adopt a more proactive approach in terms of training and making the staff aware of the public procurement procedures.

The length of time taken to approve RFPs at the SPB (mean of 4.60 ) is significantly long and detracts from service delivery. It was found that the tender document approval process takes from 2 weeks to 1 month. Recommendations in a study conducted in Sierra Leone noted that, in order to improve efficiency in the public procurement process, standard bidding documents should be developed (Government of Sierra Leone 2011:2). Consequently, it is recommended that standard bidding documents be developed to eliminate the inconsistencies in the preparation of tender documents by the procuring entities and in the approval of tender documents at the SPB. Within this context, it is suggested that the availability of standard bidding documents, proper training of staff at the various entities and decentralisation of the procurement authority to the entities will result in the elimination of the need to have the documents submitted to the SPB for approval.

\section{Stage 2: Advertising stage}

The amount of time taken to approve RFPs and adverts at the $\mathrm{SPB}$ is a problem that detracts from service delivery (mean of 4.32). This process can take up to a month and this has been attributed to the lack of technical and human resources capacity at the SPB. This lack of technical and human resources has resulted in the need to go back and forth continuously for clarifications at the SPB. As Dzuke and Naude (2015:6) indicate, the requirements of the legal framework require that activities, such as approval of requests for quotations and adverts, tender closing as well as evaluation thereof, must involve the SPB. Therefore, it is recommended that the process of approving of the documents be delegated to the procuring entities through the decentralisation of the procurement authority to 


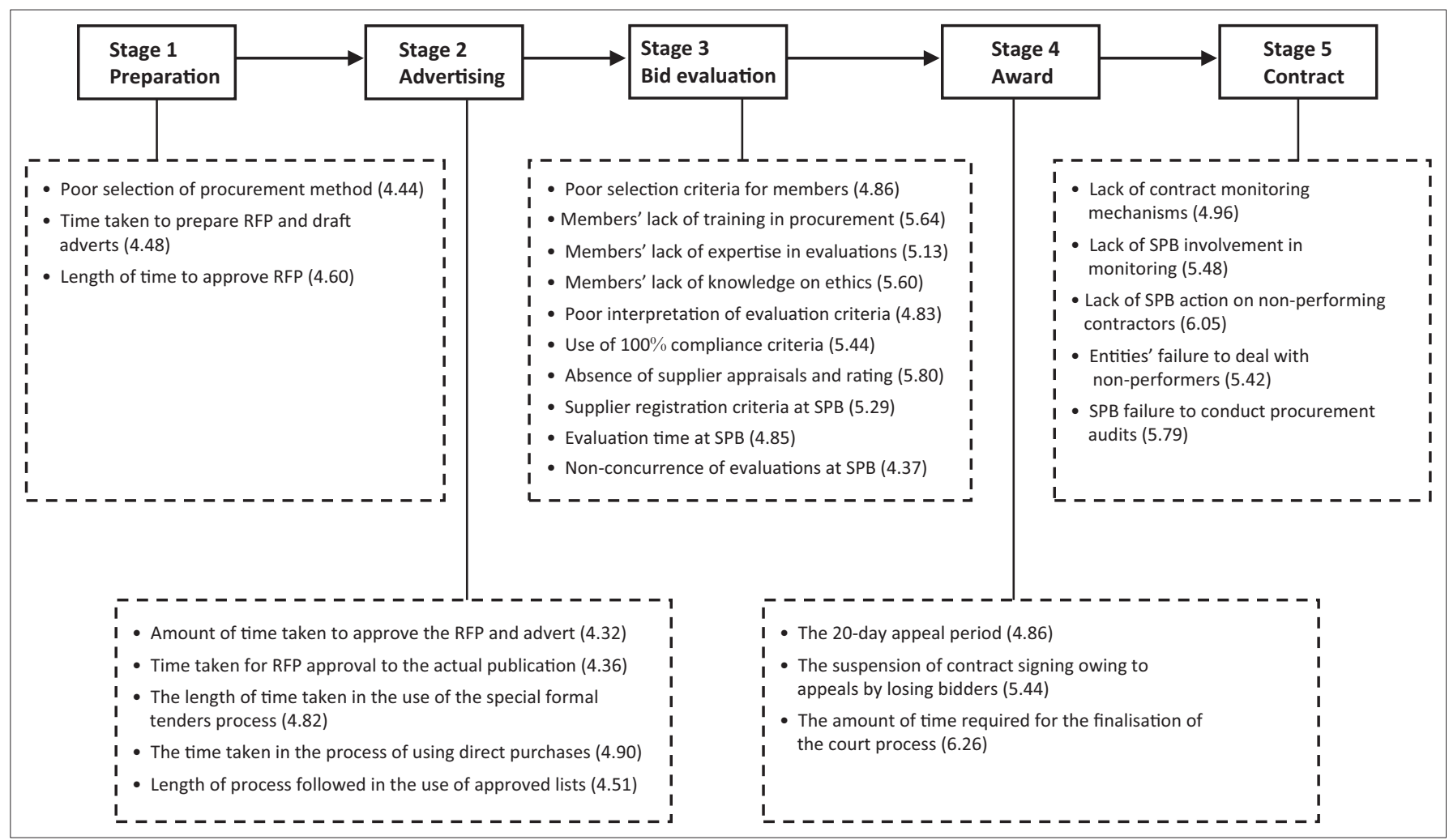

RFP, request for proposal; SPB, State Procurement Board.

FIGURE 2: Summary of significant procurement problems that detract from service delivery in Zimbabwe.

the entities. The SPB could then take on the role of overseer authority.

The amount of time taken from RFP approval to the actual publication (mean of 4.36) owing to the inflexible legal requirements that tenders should first be published in the government gazette is a challenge that detracts from service delivery. This challenge has resulted in delaying the procurement process. For example, failure to pay on Monday for the advertisement to be placed in the gazette on Friday means that the advertisement will be placed 1 week later. It is recommended that tenders should be payable on any day of the week (during working hours) to improve flexibility.

The length of the time taken on the use of the special formal tenders process (mean of 4.82), the time taken in the process of using direct purchase (mean of 4.90) and the length of the process followed in the use of approved lists (mean of 4.51) are long. These delays are attributed to the need to have all of them approved by the SPB. Musanzikwa (2013:125) concurs as he remarks that the need to comply with SPB procedures resulted in major delays in government projects. While there are procurement methods that are suitable for special circumstances, such as urgency, specialised purchases or proprietary purchases, the delayed approval process defeats the purpose. It is recommended that the procuring entities be granted the authority to supervise and conclude these processes without the active involvement of the SPB in order to reap the expected benefits of quicker response rates using these methods. The SPB could take on the role of monitoring the procurement processes and conduct regular audits at the entities to ensure compliance with procedures.

As the most significant problems emanate from the amount of time taken to approve the activities in the advertising stage, it is recommended that the activities be decentralised to the procuring entities. This is supported by Thai (2008:9), who remarks that an important method of achieving increased efficiency in procurement is through the decentralisation of authority and procurement processes. This will quicken the process, and such decentralisation will be made possible if the public procurement regulatory framework is revised to embrace that.

\section{Stage 3: Bid evaluation stage}

Poor selection criteria of evaluation committee members (4.86) can be attributed to Section 14 of the Procurement Regulations, which states that the prerogative of selecting procurement committee members lies with the Accounting Officers. The Regulations do not explicitly indicate who should be on the committee in terms of position, qualifications and experience. This results in subjectivity in the selection process. It is therefore recommended that the Accounting Officers should make it mandatory that members be selected on the basis of meeting set minimum criteria in terms of qualifications and expertise, which would improve the standard of evaluations.

Evaluation team members' lack of training in procurement (mean of 5.64) and team members' lack of expertise in tender 
evaluation (mean of 5.13) are problems that detract from service delivery and have resulted in the poor quality of tender evaluations. This is in line with the findings of Ameyaw et al. (2012:61). It is recommended that members undergo training on how to evaluate tenders by the SPB. It is also recommended that the procurement authority be delegated to the procuring entities through the reform of the procurement regulations so that the SPB can diligently perform training, monitoring, supervision and audits of entities. Public procurement should also be included in the curricula of universities and colleges so that staff in the procuring entities are exposed to training, in addition to continuous refresher courses in this field.

Evaluation team members' lack of knowledge of procurement ethics (mean of 5.60) has resulted in poor procurement decisions being made and officers failing to distinguish between right and wrong - the result being the cultivation of corrupt tendencies (Musanzikwa 2013:125; Osei-Tutu, Badu \& Owusu-Manu 2009:236). As a result, Zimbabwe is ranked as one of the most corrupt countries (156 out of 174) (Corruption Perception Index 2014:5). Therefore, it is recommended that a standard code of ethics and conduct for all procuring entities be set, to guide appropriate behaviour of officers in the execution of their work.

Poor interpretation of evaluation criteria (mean of 4.83) is attributed to the evaluation team members' lack of training in procurement (mean of 5.64), and the evaluation team members' lack of expertise in tender evaluation (mean of 5.13). Training is recommended with an emphasis being placed on public procurement in the curricula of the universities and training institutions.

It has been noted that the use of the $100 \%$ compliance method (mean of 5.44) of evaluation has resulted in tenders being awarded to bidders without the required capacity and expertise. This is aggravated by the absence of supplier appraisals (mean of 5.80). The use of the concept of the most economically advantageous tender as the evaluation criterion is recommended, as it results in tenders being awarded to bidders with the appropriate capacity and expertise to complete the projects.

It was in the comments section, that supplier approved list registration criteria at the SPB (mean of 5.29) is the reason why tenders have been awarded to bidders without the required capacity and expertise to carry out government contract. This is because the registration criteria at the SPB are based only on submission of documents and payment of $\$ 100$, with no supplier appraisal to determine the capacity of the suppliers as a consequence of lack of resources. It is recommended that the procurement authority be delegated to the entities that are better resourced to carry out the supplier appraisals. This will result in only suppliers with capacity and expertise being placed on the approved list and carrying out government contracts.
The amount of time taken for evaluation at the SPB (mean of 4.85) has been blamed on capacity constraints at the SPB. Devolution to the procuring entities of authority to evaluate and award tenders is necessary to improve the evaluation process, because entities have the resources to ensure that the processes are carried out with better precision and speed (Balaba 2012). Non-concurrence of entity and SPB evaluation (mean of 4.37) was the result of differing perceptions between the SPB and the procuring entity concerning what is critical in an evaluation. The SPB is concerned with compliance issues, while entities are concerned with the technical, financial and resource capabilities of suppliers. Thus, entities are more inclined to make an informed procurement decision than the SPB, and it is recommended that the function be delegated to the procuring entities so that service delivery can be improved.

\section{Stage 4: Award stage}

The 20-day period provided for losing bidders to lodge appeals at court (mean of 4.86) is a challenge that detracts from service delivery because such a long period impacts on the suspension of the procurement proceedings and contract signing (mean of 5.44) unless a certificate of urgency has been obtained. It is recommended that the appeals period be limited to 7 days to reduce the effect of prolonging the procurement proceedings.

The amount of time required for the finalisation of the court process (mean of 6.26) is a significant challenge that detracts from service delivery owing to the time taken to conclude cases at the administrative courts. It was noted from the comments section that this can take as long as 6 months. This results in the non-delivery of the service and suspension of procurement proceedings until such time as the case has been concluded.

The devolution of authority to manage the procurement process by the entities will likely enhance more precise evaluations, resulting in reduced rate of appeals.

\section{Stage 5: Contract stage}

The lack of contract monitoring mechanisms (mean of 4.96) and the lack of SPB involvement in contract monitoring (mean of 5.48) have resulted in contractors taking longer to deliver government contracts. Contractors have also abandoned some unfinished contracts. A proportion of these contractors would have been given some advance payment and they are aware of the SPB's lack of contract monitoring. Contract monitoring can be better done by the entities that sign the contracts and have resources to carry out the function properly, and it is therefore recommended that the function be carried out entirely by the entities without the involvement of the SPB.

Although the SPB is the body empowered, in terms of Section 25 of the Procurement Regulations, to deal with suppliers failing the government, lack of SPB action when suppliers 
fail to perform (mean of 6.05) is a challenge that detracts from service delivery. It is recommended that Section 25 of the Procurement Regulations be revised to delegate authority to the procuring entities to monitor contracts and to deal with non-performing contractors. These entities are better resourced in both human and material requirements to carry out such activities. The SPB role will then be to monitor and supervise the entities in terms of the execution of the mandate.

Failure by entities to take action when suppliers do not meet performance standards (mean of 5.42) is because it is the SPB that has the authority to deal with delinquent suppliers, and the procuring entities are not empowered to deal with them but rather only to refer them to the SPB. As recommended previously, the solution lies in the delegation of authority to the entity to reprimand non-performing suppliers.

Failure to conduct procurement audits by the SPB (mean of 5.79) can be attributed to resource constraints and has been cited as a reason as to why the entities continue to commit mis-procurements. The absence of audits to identify areas needing improvement has resulted in the procuring entities continuously making the same mistakes and facing the same challenges in the procurement process. It is recommended that, with the devolution of procuring authority to the procuring entities, the SPB would be able to channel its resources to audits and monitoring, and generally assume the role of overseer.

\section{Limitations}

The limitations of this study are as follows:

- Accessing certain information from some public entities, particularly those that deal with national security issues, was a challenge as some information in these areas is deemed to be confidential.

- Since no similar research has been done in Zimbabwe, some of the respondents may have felt that it was aimed at exposing their technical shortcomings and other inadequacies.

- Problems in the public procurement process were identified through secondary data and the interviews with participants at the public entities. The implication is that not all problems may have been identified.

As a way forward, it is suggested that future research be undertaken among the local authorities (both rural and urban) to determine whether they are facing similar problems and how these challenges detract from service delivery in their respective areas.

\section{Conclusion}

This study has provided a number of insights and made some recommendations, which, if adopted, can lead to the improvement of service delivery in the Zimbabwean public sector. However, the insights of the study should be viewed in terms of the limitations discussed.
Through the literature research, it was established that public entities face problems in the dispensing of public service owing to the problems in the Zimbabwean public procurement process. This was further evidenced in the interviews, which revealed problems in the public procurement process that detract from service delivery - the first phase of the study. The aim of the interviews with the five entities was to try and determine the problems in the public procurement process, while the questionnaire sought to determine the extent of these challenges and whether they detract from service delivery.

The second phase of the empirical research used structured questionnaires for a full-scale survey. The identified problems in the public procurement process from the literature review and the first phase of the study were tested and ranked. The findings indicated that the responding public entities agreed on the extent and magnitude of the problems experienced.

The study found that the most significant problems that detract from service delivery in the Zimbabwean public sector occur in the advertising, bid evaluation and contract stages. The involvement of the SPB delays the procurement processes and is the basis of many problems in the public procurement process that detracts from service delivery. The majority of respondents remarked that the public procurement legal framework gives excess control and authority to the SPB. As discussed in the findings, this is a problem for public entities staff who find it difficult to execute their duties because of the bureaucracy and inefficiency experienced at the SPB. This is at the expense of service delivery.

The findings of this study contribute to the body of knowledge in the field of public procurement in the Zimbabwean public sector, and it provides recommendations on how service delivery can be improved. Recommendations are made for public entities in Zimbabwe as a whole with regard to how the identified problems can be overcome. Suggestions are provided for stakeholders with regard to how the public procurement process could be improved in order to enhance service delivery. These recommendations could be used as a basis for future research studies.

The research study contributes to the performance of the public sector in Zimbabwe, given that public procurement is an important part of the government value chain. The objective of the public sector is to provide services to the public, and public sector organisations have an obligation to deliver quality service at the lowest possible cost. Since not many studies have focused on public procurement in Zimbabwe and this study is the first to identify problems in the public procurement process that detract from achieving service delivery, this study makes a contribution to practice in public procurement, focuses attention on the challenges that detract from service delivery and suggests how the process could be improved to enhance service delivery. 


\section{Acknowledgements Competing interests}

The authors declare that they have no financial or personal relationships that may have inappropriately influenced them in writing this article.

\section{Authors' contributions}

A.D. collected and analysed the data. M.J.A.N. was the project leader, made conceptual contributions and finalised the article.

\section{References}

ADB/OECD, 2008, 'Fighting Bribery in public procurement in Asia and the Pacific', in Proceedings of the 7th Regional Seminar on Making International Anti-Corruption Standards Operational, Asian Development Bank/Organisation for Economic Cooperation and Development Anti-Corruption Initiative for Asia and the Pacific, Indonesia, November 05-07, 2007, pp. 1-247.

Ambe, I.M. \& Badenhorst-Weiss, J.A., 2012, 'Procurement challenges in the South African Public Sector', Journal of Transport and Supply Chain Management 1, 242-261. https://doi.org/10.4102/jtscm.v6i1.63

Ameyaw, C., Mensah, S. \& Osei-Tutu, E., 2012, 'Public procurement in Ghana: The implementation challenges to the Public Procurement Law 2003 (Act 663)', International Journal of Construction Supply Chain Management 2(2), 55-65. https://doi.org/10.14424/ijcscm201012-55-65

Balaba, D., 2012, Presentation on public procurement in Uganda: Achievements, challenges and future: Procurement reforms: Impact on service delivery in the local governments, Chief Administrative Officer, Association of Local Government Administrative Officers of Uganda, Kampala.

Besley, T. \& Ghatak, M., 2007, 'Reforming public service delivery', Journal of African Economies 16(1), 127-156. https://doi.org/10.1093/jae/ejm026

Chigudu, P., 2014, 'Public Procurement in Zimbabwe: Issues and challenges', Journal of Governance and Regulation 3(4), 21-26.

Chimberengwa, P.T., Masuka, N., Gombe, N.T., Tshimanga, M. \& Bangure, D., 2015, 'Procurement process at Gwanda Provincial Hospital, Matabeleland South Province, Zimbabwe, 2012: A descriptive cross sectional study', Austin Journal of Public Health Epidemiology 2(1), 1018, 1-6.

Chirisa, T., 2010, 'Social development in Zimbabwe', discussion paper prepared for the Development Foundation for Zimbabwe (DFZ), December 2010, viewed 23 September 2016, from http://www.dfzim.com

Corruption Perception Index, 2014, Transparency International, viewed 26 October 2015, from https://www.transparency.org/cpi2014/results

Creswell, J.W., 2013, Research design; Qualitative, quantitative and mixed methods approach, Sage Publications, Thousand Oaks, CA.

Dza, M., Fisher, R. \& Gapp, R., 2013, 'Procurement reforms in Africa: The strides, challenges, and improvement opportunities', Public Administration Research 2(2), 49-57. https://doi.org/10.5539/par.v2n2p49

Dzuke, A. \& Naude, M.J.A., 2015, 'Procurement challenges in the Zimbabwean public sector: A preliminary study', Journal of Transport and Supply Chain Management 9(1), 1-9. https://doi.org/10.4102/jtscm.v9i1.166

Finstad, K., 2010, 'Response interpolation and scale sensitivity: Evidence against 5 point scales', Journal of Usability Studies 5(3), 104-110.

Gayed, Y.E.L., 2013, 'The influencing factors of public procurement policy development-the case of Libya', Doctoral thesis, Salford Business School, University of Salford, Manchester, United Kingdom.

Government of Sierra Leone, 2011, IPFMRP terms of reference for updating the National Public Procurement Legal Framework for the Government of Sierra Leone, Integrated Public Financial Management Reform Programme, The Ministry of Finance and Economic Development, Government of Sierra Leonne, Freetown, Sierra Leonne.

Hetland, J., 2012, Realising the potential of women vendors, International Trade Centre: Trade Forum Editorial, Washington, pp. 1-37.

Hunja, R., 2003, 'Obstacles to public procurement reform in developing countries', in S. Arrowsmith \& M. Trybus (eds.), Public procurement: The continuing revolution, pp. 13-22, Kluwer Law International, The Hague.

International Republican Institute, 2015, Survey on Local Governance and Constitutionalisation in Zimbabwe, December 20, 2014 to January 23, 2015 International Republican Institute-Advanced Democracy Worldwide, viewed 22 September 2016, from http://www.IRI.org/Survey-Zimbabwe/1/assets/basic html/page4.html

Johnson, P.F. \& Flynn, A.E., 2015, Purchasing and supply management, 5th edn., McGraw-Hill Education, New York.

Karombo, T., 2014, Zimbabwe's Netone under fire for poor performance, The Herald, 11 February, viewed 15 September 2016, from http://www.herald.co.zw
La Harpe, D. \& Le Roux, S.P., 2009, Public Procurement Law: A comparative analysis, Doctoral Study: University of South Africa, Pretoria, viewed 12 October 2016, from $\mathrm{http}: / /$ hdl.handle.net/10500/3848

Le Grand, J., 2009, The other invisible hand: Delivering public services through choice and competition, Princeton University Press, Princeton, NJ.

Licenji, A., 2015, 'Standards and challenges of public procurement', European Scientific Journal 11(25), 229-240.

Livhuwani, T.V., 2012, Impact of the supply chain management on service delivery: The case study of Provincial Department of Economic, Development, Environment and Tourism in the Limpopo Province, Unpublished dissertation, Faculty of Management and Law (School of Leadership), University of Limpopo.

Mahmood, S.A., 2010, 'Public procurement and corruption in Bangladesh-confronting the challenges and opportunities', Journal of Public Administration and Policy Research 2,103-111.

Mamiro, G.R., 2010, Value for money: The limping pillar in public procurementexperience from Tanzania, viewed 28 October 2016, from http://www.ippa.org/ IPPC4/Proceedings/01ComparativeProcurement/Paper1-2.pdf

McDaniel, C. \& Gates, R., 2013, Marketing research essentials, Wiley, Washington, DC.

Monczka, R., Handfield, R., Giunipero, L. \& Patterson, J.L., 2008, Purchasing and supply chain management, Cengage Learning, New York.

Murimoga, R. \& Musingafi, M.C.C., 2014, 'Local governance and service delivery in Zimbabwean local authorities-the case of Harare and Masvingo Urban municipalities', International Journal of Public Policy and Administration Research 1(3), 94-107.

Musanzikwa, M., 2013, 'Public procurement system challenges in developing countries: The case of Zimbabwe', International Journal of Economics, Finance and Management Sciences 1(2), 119-127. https://doi.org/10.11648/j.ijefm. 20130102.18

Mushanyuri, B.E., 2014, Call for procurement System review, The Herald. Features Opinions and Analysis, 14 August, viewed 19 September 2016, from http://www. herald.co.zw/call-for-procurement-system-review/

Mutava, C., 2012, 'Impact of public procurement procedures on delivery of maintenance', Master of arts dissertation, University of Nairobi, Kenya.

Naude, M.J., Ambe, I.M. \& Kling, R., 2013, 'Supplier relationship management Anathema for the South African public procurement sector', Journal of Transport and Supply Chain Management 1, 1-8. https://doi.org/10.4102/jtscm.v7i1.93

Nkinga, N.S.D., 2003, 'Public procurement reforms -The Tanzanian experience', paper presented at the WTO - World Bank Region Workshop on Procurement Reforms presented at the WTO - World Bank Region Workshop on Procurement Reforms
and Public Procurement for the English - Speaking African Countries held at the Royal Palm Hotel, Dar Es Salaam, Tanzania, 14-17th January.

Osei-Tutu, E., Badu, E. \& Owusu-Manu, D., 2009, 'Exploring corruption practices in public procurement of infrastructural projects in Ghana', International Journal of Managing Projects in Business 3(2), 236-256. https://doi.org/10.1108/ 17538371011036563

Owuoth, G.G. \& Mwangangi, P., 2015, 'Effect of Public procurement regulations on procurement performance in the public sector in Kenya-A case of Rura Electrification Authority', International Journal of Social Sciences management and Entrepreneurship 2(1), 171-184.

Pearse, N., 2011, 'Deciding on the scale granularity of response categories of Likert type scales: The case of a 21 point scale', Electronic Journal of Business Research Methods 9(2), 159-171.

Radhakrishna, R.B., 2007, 'Tips for developing and testing Questionnaires/ instruments', Journal of Extension 45(1), viewed 03 October 2012, from http:// www.joe.org

Ringwald, K. \& Ndercaj, V., 2014, 'Driving economic development through public sector procurement: An introductory study to identify the common challenges sector procurement: An introductory study to identify the common challenges
facing public sector procurement in Sub-Saharan Africa', Working Paper: $23 \mathrm{rd}$ facing public sector procurement in Sub-Sahar
Annual Ipsera Conference, April 13-16, 1-19.

Roodhooft, F. \& Abbeele, A.V.D., 2006, 'Public procurement: Consulting services evidence and comparison with private companies', International Journal of Public Sector Management 19(5), 490-512. https://doi.org/10.1108/09513550 610677799

Sarfo, P.A. \& Baah-Mintah, R., 2013, 'Assessing the Effect of the Procurement Act (663) on the Public Financial Management in Ashanti Region', American Journal of Rural Development 1(4), 91-98.

Sekaran, U. \& Bougie, R., 2009, Research methods for business. A skill building approach, 5th edn., Wiley, Chichester, West Sussex.

Seidu, S.S., Fatawu, A. \& Ahmed, S., 2014, 'Assessing the contribution of Public Procurement in revenue mobilization in Ghana', International Journal of Economics, Commerce and Management 2(9), 1-20.

Shaw, F.N., 2010, The power to procure: A look inside the City of Austin procurement program, Texas State University, Austin, TX.

Thai, K.V., 2008, 'Measuring losses to public procurement corruption: The Uganda case', paper presented at the 3rd International Public Procurement Conference Proceedings, University of Twente Amsterdam, The Netherlands, August 28-30, 2008, pp. 1067-1095.

Thuo, C.W. \& Njeru, A., 2014, 'Effects of public procurement reforms on service delivery at National Spinal Injury Hospital in Nairobi', International Journal of Business and Commence 3(8), 70-81.

Tsabora, J., 2014, 'Public procurement in Zimbabwe-law policy and practice', African Public Procurement Law Journal 1(APPL/1), 1-21.

United Nations Development Program/Inter-Agency Procurement Services Office, 2006, Sustainable procurement guidelines: Economic, social and environmental considerations in public procurement, viewed 10 April 2015, from http://www. unep.org 
Uromi, S.M., 2014, 'Challenges facing public procurement information in some African countries namely South Africa, Uganda, Zimbabwe and Tanzania', International Journal for Innovation Education and Research 2(7), 54-60.

Uyarra, E. \& Flanagan, K., 2010, 'Understanding the innovation impacts of public procurement', European Planning Studies 18(1), 123-143. https://doi.org/ 10.1080/09654310903343567

Van Weele, A.J., 2014, Purchasing and supply chain management, 6th edn., Cengage Learning, Singapore.

Vellapi, M., 2010, Public procurement for sustainable development, Research paper on sustainable public procurement, Ministry of Highways, Sri Lanka, viewed 10 June 2013, from http://www.ippa.org/IPPC4/Proceedings/07GreenProcurement/ Paper7-11.pdf
Wanna, J., Butcher, J. \& Freyens, B., 2010, Policy in action: The challenge of service delivery, New South Publishing, Sydney.

Weishaar, E., 2013, Cartels, competition and public procurement: Law and economic approaches to bid rigging, Edward Elgar, Cheltenham.

Zimbabwe Government, 1999, Procurement Act (Chapter 22:14), Act No. 2 of 1999 Printed by the Government Printer, Zimbabwe Government, 2002, Procurement regulations, Statutory Instrument (S.I.) 171 of 2002, Printed by the Government Printer, Harare.

Zimbabwe Government, 2012, Statutory Instrument (S.I) 160 of October 2012, Printed by the Government Printer, Harare.

Zimbabwe, 2012, Statutory Instrument (S.I.) 159 of October 122012 (Chapter 22:14), Printed by the Government Printer, Harare. 